\title{
Business Starters and Credit Rationing
}

\begin{abstract}
This paper investigates which business starters experience credit rationing by simultaneously analyzing which business founders apply for credit and which are refused. We argue that credit denial depends largely on the entrepreneurs' commitment and signals regarding the repayment of the loan and the success chances of the proposed business. Our empirical analysis is based on a sample of 1140 potential business starters in the Dutch county South Limburg. Our findings show that commitments drive the credit application and approval, while the effects of signals are mixed. The findings also suggest that business founders have a pretty good idea regarding whether their applications will be honored or not.
\end{abstract}

KEY WORDS: Self-employment, capital market imperfections, credit rationing.

JEL CLASSIFICATIONS: G20, J23, L26.

\section{Small businesses and access to bank funds}

Entrepreneurial activity is hampered by limited access to financial resources. The empirical evidence of capital market imperfections in the context of starting businesses is widespread. For instance, Evans and Jovanovic (1989) and Johansson (2000) report that personal wealth facilitates an individual's possibility to become self-employed. Likewise, the receipt of an inheritance or other windfall gains raises the probability of entering self-employment (Holtz-Eakin et al. 1994a, b; Lindh and Ohlsson, 1996; Blanchflower and Oswald, 1998).

One reason for the lack of financial resources available to starting businesses is that banks hesitate to lend funds to businesses in general and

Final version accepted on November 2006.

Boris F. Blumberg and Wilko A. Letterie

Department of Organization \& Strategy

University Maastricht

Tongersestraat 53, Maastricht, 6211 LM, The Netherlands

E-mail: b.blumberg@os.unimaas.nl small enterprises in particular. ${ }^{1}$ Ang $(1991,1992)$ discusses capital market imperfections in the context of small establishments and observes that in judging credit applications banks face several serious information problems. First, as usual the applicant's information concerning the project's prospects is usually better than that of outsiders. Information asymmetries may be substantial in the context of small businesses because of the relatively high fixed cost of gathering information banks incur for small transactions. Furthermore the smaller number of repeated transactions; the smaller incentives of outside analysts to collect information; and the fewer instruments available to small businesses to signal their credibility yield conditions under which serious information asymmetries prevail. Second, the quality of the data provided by small business owners for review by stakeholders like banks is often poor due to a lack of management experience or staff capable to produce useful information. Ang (1991, 1992) notes that an advantage of small businesses is that the managers are often the owners as well. This feature may resolve the manager versus ownership problem. However, he also argues that conflicts of interest between the owner and other stakeholders, like suppliers exercising monopoly power, may be more serious.

Since banks find it hard to determine whether a project is a good or bad risk, a supply shortage of loans may result in equilibrium. Then some business starters will not be able to receive a loan even though their project yields a positive net expected value, because banks ask for a high-risk premium and ration credit (Stiglitz and Weiss, 1981). Therefore, any business owner seeking bank financing needs to overcome the hesitation and doubts of banks. An extensive theoretical literature exists that considers which instruments may be used by banks to distinguish between bad and good loans and to mitigate the 
risk of moral hazard (i.e. when the borrower does not put enough effort in to the business). Such instruments include collateral the bank can seize if the borrower defaults and requests to hold the borrower liable for repayment by e.g. personal guarantees. Alternatively, the bank can assess the loan quality by looking for signals regarding the future prospects for the business.

However, very little empirical knowledge exists about the characteristics of individuals who would like to start a business, but are restricted in doing so because of credit rationing by banks. ${ }^{2}$ Although a number of empirical studies on credit denials and applications have been published, the overall picture remains vague and ambiguous as studies differ in their research objectives, the used explanatory variables and as already mentioned the addressed population and statistical methods employed. A couple of studies have a particular interest in whether credit application and denial differs by gender or race implying a possible presence of discrimination by banks (see, e.g. Cavaluzzo and Cavaluzzo, 1998; Blanchflower et al., 1998; Raturi and Swamy, 1999; Levenson and Willard, 2000; Storey, 2004). Even after the credit worthiness of the respondent is controlled for, these studies show that blacks are significantly less likely to receive credit, while there are no differences for other ethnicities or women. All studies on credit denial include the risk of the loan, but use rather different indicators. Many studies build upon human capital theory and look at education, age, work experience and social background to determine whether a lender carries risks or not (see, e.g., Cavaluzzo and Cavaluzzo, 1998; Honig, 1998; Raturi and Swamy, 1999; Biggs et al., 2002; Storey, 2004). Across these studies, indicators related to human capital and demographics are not significant in the denial decision. Several studies assess the loan risk by taking characteristics of the firm, such as size, age and legal status, or financial indicators, such as profit, current loans or capital assets (Cavaluzzo and Cavaluzzo, 1998; Blanchflower et al., 1998; Biggs et al., 2002; Storey, 2004). Across studies, the effects of those indicators on the denial decision are either mixed or non significant. Summarizing it can be stated that a consistent overall picture of the determinants of credit approval and denial is still missing. Therefore, we propose in this paper to inspect the issue from a slightly different angle. Rather than looking at risk of a loan, we look at whether business founders or owners can reduce credit denial through giving commitments or sending reliable signals.

The first objective of this paper is to provide some insight into the conditions under which banks are willing to approve loan requests. In fact, we analyze data collected among 1140 individuals living in South Limburg (The Netherlands) who considered becoming self-employed in 1998 and 1999. Of them 342 applied for a bank loan to start their business. It should be noted that the sample used forms an interesting contribution to the current literature in two aspects. First, this study provides an analysis of a European country, while previous studies investigated either the US (e.g., Cavaluzzo and Cavaluzzo, 1998; Levenson and Willard, 2000) or developing countries (e.g., Honig, 1998; Raturi and Swamy, 1999; Biggs et al., 2002; Storey, 2004). Second, the sample consists of potential new business founders, a group which is particularly likely to face financing difficulties. The survey provides information about whether these individuals made an application at a bank and it indicates to which extent these applications have been granted. Moreover, the data are very rich in additional information providing us with multiple indicators for commitments and signals a business founder might give to enhance the approval chances of the credit application. Thus, we are able to investigate whether business founders providing commitments and sending signals are more likely to receive credit.

The second objective of the paper is to investigate whether business starters have some understanding of the rating criteria employed by banks to determine whether to grant a loan or not. If the probability to obtain a loan is small there is little incentive to apply. Individuals who do not apply because they fear their request will be denied are also affected by credit rationing. As understanding the true extent of credit rationing needs to account for discouraged application behavior (Levenson and Willard, 2000; Kon and Storey, 2003), we intend to bridge the gap in the current literature (Parker, 2004) by analyzing denial and application rates simultaneously with a bi-variate probit model rather than estimating 
application and denial separately (see, e.g., Cavaluzzo and Cavaluzzo, 1998; Raturi and Swamy, 1999; Storey, 2004) or in sequential steps (Levenson and Willard, 2000). This approach allows us to determine which factors induce both direct credit rationing by the banks and indirect credit rationing because of discouraged application behavior. Moreover it enables us to investigate whether business starters have some understanding of the credit rationing policy of the bank. Such understanding exists if a variable observable to the bank implies a higher (lower) probability of denial and a lower (higher) probability of application simultaneously.

The paper proceeds as follows. In section 2 we develop a bivariate model accounting for sample selection by which we can identify the characteristics of individuals who are more likely to experience credit rationing. This model determines the probability that an individual is denied a request for a loan and incorporates the decision to apply for a loan or not. In section 3 we provide an overview of the empirical and theoretical literature that is relevant to our subject. Section 4 describes the data we analyze. The estimation results are depicted in section 5 and section 6 concludes.

\section{The identification of credit rationing}

To conduct an analysis of the bank's rationing behavior, we assume that the decision to approve or deny a credit request depends on a set of lenders' characteristics observed by the bank. These features are represented by the vector $X$. We assume that the bank observes $X$ and on the basis of the observed characteristics determines the project's risk and quality (cf. Guiso, 1998). Suppose that $Z^{*}$ is a latent variable for the bank's decision whether to grant the loan or not. When $Z^{*}>0$ the signals observed induce the bank to classify the project as a 'lemon' and to ration the credit extended to it accordingly. We define $Z^{*}$ as follows:

$$
Z^{*}=X \beta+\mu
$$

where $\beta$ is a vector of coefficients and $\mu$ is an error term. Let $Z$ be a dummy variable, which obtains the value 1 if the firm is denied credit by the bank and zero otherwise.

The first part of the empirical model explains the probability that a bank approves a credit application and focuses on the supply side of the market for new business financing. However, business starters - even those with very promising business ideas - may not apply for credit because they expect their efforts to be unsuccessful anyway. Especially if the cost for a credit application is substantial and the probability of being rejected is high, it may be optimal not to apply (Levenson and Willard, 2000). Therefore, an analysis of the credit denial is likely to be biased towards finding too small incidence of being denied if one does not account for the decision to apply for credit as we described previously. We solve this problem by estimating a model that takes into account the application process and the outcome of the application simultaneously as follows. We observe the bank's decision conditional upon the event that an individual has applied for a loan. The decision to apply depends on a number of characteristics of the potential applicant, which are represented by a vector $W$ and are observable to the econometrician. Let $Y^{*}$ be a latent variable for the decision whether to apply for a loan or not. When $Y^{*}>0$, the information is such that an application is expected to yield a positive evaluation by the bank. We define:

$$
Y^{*}=W \gamma+\varepsilon
$$

where $\gamma$ is a vector of coefficients and $\epsilon$ is a random error. Let $Y$ be dummy variable, which takes the value 1 if the potential business starter applies for a loan and zero otherwise.

We observe $Z$ and $X$ only if an application has occurred, i.e. if $Y=1$. Furthermore, while $\epsilon$ is defined over the whole population of individuals who considered to become self-employed, $\mu$ is only defined on the subpopulation for which $Y=1$. To model this, we assume that $\epsilon$ and $\mu$ are drawn from a bivariate normal distribution, corrected for a sample selection with a correlation coefficient of $\rho: \epsilon, \mu \sim \mathrm{N}(0,0,1,1, \rho)$. This indicates that the means of the error components are equal to zero and that the standard deviations equal 
one. Let $\Phi_{2}$ denote a bivariate normal cumulative distribution function (cdf) and $\Phi$ a univariate normal cdf. We have three categories of observations. ${ }^{3}$

$$
\begin{aligned}
Y= & 1, Z=1 \quad \text { with } \\
& \operatorname{Pr}(Y=1, Z=1)=\Phi_{2}(W \gamma, X \beta, \rho) \\
Y= & 1, Z=0 \quad \text { with } \\
& \operatorname{Pr}(Y=1, Z=0)=\Phi_{2}(W \gamma,-X \beta,-\rho) \\
Y= & 0 \quad \text { with } \quad \operatorname{Pr}(Y=0)=\Phi(-W \gamma)
\end{aligned}
$$

The log-likelihood function is:

$$
\begin{aligned}
11= & \sum_{Y=1, Z=1} \ln \Phi_{2}(W \gamma, X \beta, \rho) \\
& +\sum_{Y=1, Z=0} \ln \Phi_{2}(W \gamma,-X \beta,-\rho) \\
& +\sum_{Y=0} \ln \Phi(-W \gamma)
\end{aligned}
$$

We find estimates for $\gamma, \beta$ and $\rho$ by maximizing (4) with respect to these parameters.

\section{A closer inspection of credit denial and application}

\subsection{Commitments and signals}

The pecking order theory as proposed by Myers and Majluf (1984) suggests firm's preference for various financing forms. This pecking order theory may be applied to small companies as well. ${ }^{4}$ Most small companies are managed by only one manager who owns all the shares. These manager/owners tend to have a preference for financing forms that ensure their control over the business. Therefore, financing is usually based on "firstly personal savings and resources generated internally; secondly, short and long term debt; and thirdly, least preferred of all, new share issues that dilute control" (Lopez-Gracia and Aybar-Arias, 2000, p. 56). The vast majority of small firms and business start-ups relies on commercial banks for obtaining additional financial funds (see, e.g., Keasey and Watson, 1993; Parker, 2004). Equity financing is hardly a viable alternative, because the equity market for small firms is not well developed, most entrepreneurs lack the experience and expertise to obtain equity financing and raising equity is rather costly and therefore inefficient for smaller financing volumes.

Although bank loans are the most widely used form of small and new business financing, the exchange relation between banks and their small business clients often suffers from market imperfections, such as agency costs, information asymmetry and moral hazard. Banks are unable to assess the credit risks of a venture well and the business starters' assessment of their ventures suffers from an 'optimistic' bias. Especially in markets where it is difficult to distinguish between good and bad credit risks, these capital market imperfections result in a supply shortage of financial funds. Some new ventures with positive net present value cannot attract the necessary financial funding, because banks ask for high-risk premiums and ration credit (Stiglitz and Weiss, 1981). Banks are more likely to approve a credit request at reasonable terms, if the bank is convinced that the business is likely to succeed or if the bank is able to collect the debt, even if the proposed venture fails. Credible commitments and signals on part of the business starter are mechanisms enhancing the chance to collect the debt and the bank's ability to assess the success chance of the venture. Thus, business starters can increase their possibilities to obtain the required financial funds by giving such credible commitments and signals (Avery et al., 1998).

Table I shows how credible commitments and signals mitigate the bank's fear to invest in a venture with negative net present value and to loose the provided debt. In terms of our model introduced in section 2, each cell of Table IV refers to a broad category of explanatory variables collected in the matrix $X$. In the following, we will work out the cell entries of the figure starting at the top of the left column and then moving down. Next we turn to the right column starting at the top and moving down again.

Credible commitments guaranteeing the repayment of the debt even if the business fails are linked to collaterals underlying the loan. Such collaterals, i.e. the business starter's private 
TABLE I

Possible commitments and signals of the entrepreneurs to mitigate bank's fears

\begin{tabular}{lll}
\hline & Commitments & Signal \\
\hline $\begin{array}{l}\text { Chance to } \\
\text { recollect debt }\end{array}$ & Collaterals & $\begin{array}{l}\text { Post-failure } \\
\text { earning capacity }\end{array}$ \\
$\begin{array}{l}\text { Assessment of } \\
\text { new business } \\
\text { success chance }\end{array}$ & $\begin{array}{l}\text { Provision of } \\
\text { costly and } \\
\text { reliable } \\
\text { information } \\
\text { Investment of } \\
\text { own resources }\end{array}$ & $\begin{array}{l}\text { Founder's } \\
\text { previous career } \\
\text { Founder's } \\
\text { demographics } \\
\text { Third party } \\
\text { investments in } \\
\text { business }\end{array}$ \\
& & \\
\hline
\end{tabular}

wealth as well as a firm's re-deployable assets reduce the bank's exposure to loosing the debt (Keasey and Watson, 2000; Parker, 2004). Evidence in favor of this conjecture is provided by related studies, which show that the chance to obtain credit is significantly increased by collateral commitments, such as home ownership (Black et al., 1996; Raturi and Swamy, 1999).

The reluctance of banks to provide credit for business start-ups is also influenced by the difficulties to assess a new business. From the bank's perspective information provided by the entrepreneur is less reliable, because entrepreneurs have self-interest in exaggerating the success chances of their businesses. They can diminish this reluctance with commitments increasing the credibility of their credit application (Ang, 1991) and by providing more detailed and more reliable information, e.g., by writing a business plan. Especially if the financial plan of the venture is designed with the support of an accountant and if an accountant approves of it, banks may be more willing to grant a loan. The provision of such better information is costly for entrepreneurs and thus they have to commit their own resources before a decision on the credit application has been taken. The fact that entrepreneurs incur costs to obtain better and more reliable information about the credit application's worthiness should give the bank more faith in the success potential of their business ideas. The extent to which a business founder commits own resources to the venture also informs the banks that they are investing in a serious business idea. Own investments are a credible commitment mitigating the principal agent conflict between stockholders and bondholders, because the more own money business starters invest, the less likely it is that they take on very risky investments. ${ }^{5}$

The earning capacity of a business starter in a subsequent job, i.e. the job after the eventual failure of the business, is a signal to the bank, whether the business starter can meet his credit obligations even if the business fails (see last column of Table I). The income that a business starter earned previously is an indicator, which signals the earning capacity after an eventual failure. Furthermore, young and highly educated business starters are more likely to have a high post-failure earning capacity than older and less educated people.

Although banks care about debt-repayment, their primary objective is to allocate their funds to successful ventures, because they profit much more from a long-term relation with a new business that grows to an established firm (Storey, 1993). Banks are seeking promising new business proposals, whose risks they can evaluate well. Thus, business starters need to convince banks that their proposals are promising and can be assessed well. The broad literature on successful business start-ups offers an insight on, which factors can serve as a reliable signal for new business success. Several studies show that the founder's career affects the success of the new business (Brüderl et al., 1992; Gimeno et al., 1997; van Praag, 1996). Further, demographic characteristics and the social background of the business starter are related to success. Most studies report no significant effects of variables related to education or work experience on denial rates (see, e.g., Cavaluzzo and Cavaluzzo, 1998; Blanchflower et al., 1998; Raturi and Swamy, 1999); only Storey (2004) finds that a higher education reduces denial and increases application. Married persons are more likely to become successful entrepreneurs, because their spouses offer them additional financial and emotional support. Further, spouses often work as a relatively cheap and very reliable 'employee' in the new business or they hold a paid job, which eases the liquidity of the entrepreneur's household and allows re-investing more earnings 
into the business. Jappelli (1990) finds that married couples are less likely to be financially constrained consumers and Honig (1998) reports that married business owners in Jamaica are more likely to receive a loan. Children require care, money, effort and time, which cannot be invested in the newly founded business. As a consequence, individuals who are responsible for children had and have little opportunities to spare resources for their business and are less likely to succeed. A number of studies have shown that access to bank financing is more difficult for blacks (Bates, 1991; Munnell et al., 1996; Blanchflower et al., 1998; Cavalluzzo and Cavalluzzo, 1998; Raturi and Swamy, 1999; Storey, 2004), suggesting discrimination on ethnic background as a possible explanation.

We also explore whether multiple ownership facilitates access to bank loans. On the one hand, banks may be reluctant to provide financial support due to complex agency problems if more parties are involved in the financing of a business (Ang, 1991). On the other hand businesses founded by more than one entrepreneur pool more human capital (Cressy, 1996). Furthermore, many individuals liable for the underlying loan reduce the bank's risk in case of bankruptcy (Parker, 2004). These observations indicate that it is difficult to predict a priori whether banks appreciate the presence of other parties, who already committed their resources to a new business venture. Hence, the empirical analysis has to resolve this issue.

Above, we framed the different variables as indicators for commitments and signals, emphasizing a credit supply perspective to explain applications for loans. Some of the indicators could, however, also describe demand factors. ${ }^{6}$ In particular the amount of own equity, previous income and education can indicate such differences in demand for bank loans. From a demand perspective, the expected effects of these characteristics on credit application would be reversed. Thus business starters with larger amounts of own equity, a higher previous income and a higher level of education are less likely to apply for credit as they have lower need for external financial means. These starters, who could obtain credit but do not need it are the opposite of the discouraged borrower.
In general, we expect that the credit application's approval chance increases with the amount as well as the credibility of the commitments and signals an entrepreneur places to convince the bank that she or he is a reliable person pursuing a business idea with good success chances. Here, it should be noted that financing of new businesses solely can be based on the assessment of the potential business founder as a person and the blueprint of an idea, since past financial records do not exist. Thus, characteristics of the entrepreneur will play an even more crucial role.

\subsection{Interplay between denial and application rates}

To understand whether individuals do not apply because they expect their request to be denied we simultaneously analyze the loan application decision. If potential business starters are discouraged to apply for a loan even though their business idea is excellent, they should be considered subject to credit rationing as well (Kon and Storey, 2003). We estimate the application equation also including the explanatory variables we use for the denial decision. Individuals base their decision to apply on the application's success chance, the utility derived from receiving a loan and the application cost. In the previous section, we argued for instance that the availability of collateral and the perceived firm's success chances reduce the chance that a bank denies a loan request. Thus, business starters that can provide the required collateral are more likely to ask for a bank credit, because their higher chance of credit approval justifies incurring the costs associated with a credit application. Therefore, variables that explain a bank's decision to grant a loan are likely to affect the decision whether to apply or not. However, it may be argued that the decision to apply for a loan and the decision to write a business plan or to consult an accountant coincide to a large extent. This may cause some endogeneity problems. To circumvent this issue we disregard these commitments in the first stage decision to apply. Furthermore excluding these two variables from the application decision improves the identification of the model. Obtaining parameter estimates for our model where the variables represented by $W$ and $X$ in equations (1) and (2) are identical is 
not possible since we found the procedure searching for the maximum likelihood does not converge in this instance. To further improve identification of the parameter estimates we add a variable to the equation explaining the loan application. It counts the number of the business starter's contacts with others, who are selfemployed as well. It is reasonable to assume that such contacts improve an individual's ability to approach and convince banks. In fact these contacts may inform the applicant about the procedures employed by the bank and which bank to approach. However, bank employees are unlikely to be knowledgeable about the identity and size of an applicant's contacts. Therefore we exclude it from the equation explaining the bank's decision.

\section{Research design: used data and information}

The estimation of the model is based on a survey conducted among individuals living in the Southern part of Limburg, a Dutch province. A clear advantage of our data is that all individuals who intended becoming an entrepreneur in the years 1998 and 1999 were invited to participate in the research. The final dataset is based on computer assisted personal interviews (CAPI) with 1223 respondents, which is a response rate of $29 \%$. There is no strong evidence of nonresponse bias, though it is found that business starters were a little more likely to participate than non-starters. Of the respondents 994 started a business while 229 refrained from their original idea to become an entrepreneur (see Blumberg and Pfann, 2003 for further information on the survey). Due to partial item non-response we work with a total sample of 1140 respondents to analyze the application rate. Our sample consists of a wide range of business founders and includes many very small businesses $(35 \%$ of the founders started a business without employees and another $50 \%$ just with one or two employees). Since the data were collected only in a sub province, South-Limburg, of the Netherlands one may question whether they are representative for the country as a whole. We have compared the distribution of business start-ups across sectors in the Netherlands and in the sample and show the results in Table II.
TABLE II

Business start-ups in the Netherlands and South Limburg

\begin{tabular}{lcc}
\hline Sector & Netherlands & South Limburg \\
\hline Manufacturing & 5.5 & 5.7 \\
Construction & 11.7 & 10.2 \\
Wholesale & 6.2 & 6.2 \\
Retail & 4.2 & 15.2 \\
Catering & 3.3 & 9.3 \\
Transportation & 7.6 & 2.6 \\
Business services & 13.1 & 25.4 \\
Other & 48.4 & 25.4 \\
\hline
\end{tabular}

Numbers are percentages. Data are obtained from Dutch Statistics for the year 2000 (Statline). The data for South Limburg are based on the sample employed in this paper (see also Blumberg and Pfann, 2003).

The table indicates that some notable differences exist between the sectoral distribution of the start-up firms in our sample and those for the Netherlands. The regional (South Limburg) and country level data have similar characteristics in terms of traditional sectors (i.e. manufacturing, construction and wholesale). However, the South of Limburg seems to be an attractive area to found a firm in business services and retailing. ${ }^{7}$

Our first dependent variable is apply which is equal to one if the respondent has made a loan application and is zero otherwise. Our sample for the analysis of the denial rates is based on a sub-sample of those 342 respondents (i.e. $31 \%$ of the total sample), who applied for credit at a bank. We employ two dependent variables to measure credit rationing by two different types of loan denial. The first, fully_denied, is equal to one if the application is fully denied, and zero otherwise. According to this measure a denial occurs if the applicant cannot borrow any money at all from the bank. About $18 \%$ of the applications were completely rejected. The second variable, partly_denied, is one if the application is fully or partly denied, and zero otherwise. Hence, according to this variable a denial occurs if the applicant receives less then applied for. Approximately $29 \%$ of the applications were denied full approval. During the interviews, all respondents provided extensive information on their educational and occupational career, their social background, their 
spouse, available financial capital, the founding process and the started business.

In our theoretical part, we linked the application- and denial rates to the entrepreneurs' possibilities to give credible commitments and signals. Our data do not provide direct measurements of such commitments and signals. Rather, we use variables, which can serve as valid indicators for our theoretical constructs. Table III shows which indicators are used to measure the different commitments and signals.

The available collateral is measured with the dummy variable home ownership, which equals one, if the respondent possesses a house and zero otherwise. Commitments helping a bank to improve it's own assessment of a business proposal are measured with the variables business plan and accountant. A business plan provides the bank with additional information on the proposed venture and thereby enlarges the bank's information basis. Business and financial plans that are designed with the aid of an accountant, who has to comply with certain legal and professional standards, are less biased and consequently enrich the information basis of a bank. Another costly commitment a bank can observe is the amount of own financial resources the applicant invests. This is measured by the variable own equity.

Higher post-failure earning capacities are positively related to the variables previous

TABLE III

Used indicators for the possible commitments and signals

\begin{tabular}{|c|c|c|}
\hline & Commitments & Signal \\
\hline \multirow{3}{*}{$\begin{array}{l}\text { Chance to } \\
\text { recollect debt }\end{array}$} & \multirow[t]{3}{*}{ Home ownership } & Previous income \\
\hline & & High education \\
\hline & & Age \\
\hline \multirow{8}{*}{$\begin{array}{l}\text { Assessment of } \\
\text { new business } \\
\text { success chance }\end{array}$} & Business plan & Job similarity \\
\hline & $\begin{array}{l}\text { Advice from } \\
\text { accountant }\end{array}$ & Previously self-employed \\
\hline & \multirow[t]{6}{*}{ Own equity } & Leadership experience \\
\hline & & Parental self-employment \\
\hline & & Married \\
\hline & & Children \\
\hline & & Foreign \\
\hline & & Single ownership \\
\hline
\end{tabular}

income, high education and age. Previous income is proxied by the last year income the respondent earned and included in our analyses with one dummy variable, with income higher than HFL 25,000 as reference category. ${ }^{8}$ The survey measures income in five categories (less than 25,000; 25,000-50,000; 50,000-75,000; 75,000-100,000; more than 100,000). We employed only one dummy variable in our analysis, as preliminary analyses showed that application and denial rates only vary between the lowest income category and all other income categories. High education is measured with a dummy variable, which takes the value one if the respondent has completed higher vocational training or university and age is measured in years.

Several variables concerning the previous occupational experience as well as the demographics of the potential business starter are used as indicators for signals regarding the success chances of businesses. The variables job similarity, previous self-employment and leadership reflect the respondent's occupational experience. The latter two variables are dummy variables that take the value one if the respondent has previously been self-employed and has gained leadership experience in former jobs, respectively. They equal zero otherwise. The variable job similarity measures to what extent the tasks as a self-employed are similar to the ones performed in the previous job based on the respondent's assessment. The demographics of the respondents are described by parental selfemployment, married, children and foreign. All variables are dummy variables, which take the value one if the respondent's parents have ever been self-employed, the respondent is married, the respondent has children and the respondent is born abroad, respectively. They are equal to zero otherwise. Further, we use single ownership, as an indicator for another signal about the promising qualities of the new venture.

Finally we use two variables to measure the number of self-employed contacts. First, selfemployed contacts counts the number of an applicant's contacts who are self-employed. We also consider the variable self-employed family, friends and acquaintances. This variable counts the number of self-employed contacts who are 
TABLE IV

Descriptive statistics for individuals

\begin{tabular}{lllll}
\hline & Full sample & Apply $=1$ & Fully_denied $=1$ & Partly_denied $=1$ \\
\hline Apply $=1$ & 0.30 & - & - & - \\
Denied $1=1$ & - & 0.18 & - & - \\
Denied2 $=1$ & - & 0.29 & - & 0.58 \\
Home ownership & 0.69 & 0.75 & 0.58 & 0.52 \\
Business plan & 0.43 & 0.63 & 0.11 & 0.16 \\
Accountant & 0.10 & 0.27 & 23,988 & 27,185 \\
Own equity & 30,076 & 41,278 & 0.21 & 0.17 \\
Income $<$ HFL 25,000 & 0.18 & 0.12 & 0.31 & 0.33 \\
High education & 0.38 & 0.34 & 37 & 0.41 \\
Age & 38 & 37 & 0.40 & 0.24 \\
Job similarity & 0.44 & 0.50 & 0.31 & 0.57 \\
Previously self-employed & 0.20 & 0.21 & 0.53 & 0.39 \\
Leadership & 0.54 & 0.58 & 0.39 & 0.72 \\
Parental self-employment & 0.35 & 0.40 & 0.78 & 0.70 \\
Married & 0.78 & 0.79 & 0.77 & 0.14 \\
Children & 0.66 & 0.66 & 0.13 & 0.79 \\
Foreign & 0.06 & 0.06 & 0.76 & 2.59 \\
Single ownership & 0.75 & 0.68 & 2.81 & 0.19 \\
Self employed-contacts & 2.28 & 2.62 & 0.20 & 98 \\
Self employed family, friends & 0.18 & 0.22 & 62 & \\
and acquaintances & 1140 & 342 & & \\
Number of observations & & & \\
\hline
\end{tabular}

The numbers in the table represent the means of the corresponding variables.

family, friends and acquaintances. The reason for also considering the latter variable is that it excludes contacts who are business relations and who may in principle be observable to the bank if they are mentioned in the business plan and hence may affect the decision to grant the loan or not. See Table IV for relevant descriptives of the used variables.

\section{Empirical analysis of application and denial chances}

In this section, we study which individuals are more likely to experience credit rationing by estimating the model we presented in section two. We now turn to the question: "Who applies?" and present results in the upper part of Table V. It reveals that the two indicators related to commitments, namely home ownership and own equity, increase the chance of credit application. The results concerning signals regarding the chance to recollect the debt are mixed. A low previous income is as expected negatively related to credit application. A high education even reduces the chance that a business founder applies for a credit. Age has no significant effect. Most of the signals concerning the business success chances have no significant effect. Only job similarity increases the likelihood that an individual applies for a loan, while single ownership decreases the probability of applying for a loan. We also find that the number of self-employed contacts increases the probability of application. It is worth mentioning that our results do not depend on whether we use the variable self-employed contacts or self-employed family, friends \& acquaintances.

The lower part of Table $\mathrm{V}$ indicates under which circumstances a bank is more likely to deny an application. We find that denial is less likely to occur if the applicant owns a house. Likewise own equity lowers credit rationing in general. With respect to commitments, we note that if the applicant shows faith in the business idea by committing own resources, banks are more likely to approve a credit application. In this study we investigated writing a business plan and consulting an accountant and find that 
TABLE V

Determinants of application rates

\begin{tabular}{|c|c|c|c|c|c|c|c|c|}
\hline \multirow{2}{*}{$\frac{\text { Dependent variable }}{\text { Home ownership }}$} & \multicolumn{2}{|l|}{ Apply } & \multicolumn{2}{|l|}{ Apply } & \multicolumn{2}{|l|}{ Apply } & \multicolumn{2}{|l|}{ Apply } \\
\hline & $0.202^{* *}$ & $(0.101)$ & $0.189^{* *}$ & $(0.100)$ & $0.204^{* * *}$ & $(0.101)$ & $0.189^{*}$ & $(0.100)$ \\
\hline Own equity & $0.919^{* *}$ & $(0.462)$ & $1.070^{* *}$ & $(0.455)$ & $0.890^{* *}$ & $(0.460)$ & $1.060^{* *}$ & $(0.454)$ \\
\hline Income $<25,000$ & $-0.333^{* *}$ & $(0.115)$ & $-0.296^{* *}$ & $(0.113)$ & $-0.323^{* *}$ & $(0.115)$ & $-0.294^{* *}$ & $(0.113)$ \\
\hline High education & $-0.201^{* *}$ & $(0.085)$ & $-0.207^{* *}$ & $(0.085)$ & $-0.201^{* *}$ & $(0.085)$ & $-0.207^{* *}$ & $(0.085)$ \\
\hline Age & 0.023 & $(0.034)$ & 0.025 & $(0.034)$ & 0.024 & $(0.035)$ & 0.026 & $(0.034)$ \\
\hline Age2 & -0.001 & $(0.000)$ & -0.001 & $(0.000)$ & -0.001 & $(0.000)$ & -0.001 & $(0.000)$ \\
\hline Job similarity & $0.149^{*}$ & $(0.081)$ & $0.165^{*}$ & $(0.081)$ & $0.159^{* *}$ & $(0.081)$ & $0.168^{*}$ & $(0.080)$ \\
\hline Previously self-employed & 0.112 & $(0.106)$ & 0.120 & $(0.105)$ & 0.117 & $(0.106)$ & 0.121 & $(0.105)$ \\
\hline Leadership & 0.071 & $(0.087)$ & 0.097 & $(0.086)$ & 0.074 & $(0.087)$ & 0.097 & $(0.086)$ \\
\hline Parental self-employment & 0.140 & $(0.084)$ & 0.120 & $(0.084)$ & 0.121 & $(0.084)$ & $0.125^{*}$ & $(0.084)$ \\
\hline Married & -0.047 & $(0.117)$ & -0.023 & $(0.115)$ & -0.048 & $(0.117)$ & -0.025 & $(0.115)$ \\
\hline Children & 0.098 & $(0.105)$ & 0.104 & $(0.104)$ & 0.102 & $(0.106)$ & 0.105 & $(0.105)$ \\
\hline Foreign & 0.170 & $(0.166)$ & 0.169 & $(0.163)$ & 0.158 & $(0.166)$ & 0.164 & $(0.163)$ \\
\hline Single ownership & $-0.212^{* *}$ & $(0.092)$ & $-0.241^{* *}$ & $(0.091)$ & $-0.217^{* *}$ & $(0.092)$ & $-0.243^{* *}$ & $(0.091)$ \\
\hline Self-employed contacts & $0.080^{* *}$ & $(0.024)$ & - & - & $0.084^{* *}$ & $(0.024)$ & - & - \\
\hline $\begin{array}{l}\text { Self-employed family, } \\
\text { friends and acquaintances }\end{array}$ & - & - & $0.363^{* *}$ & $(0.151)$ & - & - & $0.368^{* *}$ & $(0.149)$ \\
\hline Constant & -0.856 & $(0.654)$ & -0.794 & $(0.639)$ & -0.894 & $(0.654)$ & -1.222 & $(1.424)$ \\
\hline Dependent variable & \multicolumn{2}{|l|}{ Fully_Denied } & \multicolumn{2}{|c|}{ Fully_Denied } & \multicolumn{2}{|c|}{ Partly_Denied } & \multicolumn{2}{|c|}{ Partly_Denied } \\
\hline Home ownership & $-0.520^{* *}$ & $(0.162)$ & $-0.608^{* *}$ & $(0.265)$ & $-0.582^{* *}$ & $(0.191)$ & $-0.620^{* *}$ & $(0.201)$ \\
\hline Business plan & -0.095 & $(0.082)$ & -0.133 & $(0.132)$ & $-0.350^{* *}$ & $(0.160)$ & $-0.438^{* *}$ & $(0.211)$ \\
\hline Accountant & $-0.264^{*}$ & $(0.144)$ & -0.381 & $(0.264)$ & $-0.275^{*}$ & $(0.160)$ & $-0.330^{*}$ & $(0.192)$ \\
\hline Own equity & $-1.070^{* *}$ & $(0.535)$ & $-1.300^{* *}$ & $(0.685)$ & $-1.030^{*}$ & $(0.632)$ & -1.120 & $(0.864)$ \\
\hline Income $<25,000$ & $0.318^{* *}$ & $(0.147)$ & $0.353^{* *}$ & $(0.174)$ & 0.294 & $(0.182)$ & 0.237 & $(0.250)$ \\
\hline High education & 0.147 & $(0.110)$ & 0.108 & $(0.146)$ & 0.149 & $(0.134)$ & 0.112 & $(0.183)$ \\
\hline Age & -0.014 & $(0.044)$ & -0.005 & $(0.054)$ & -0.049 & $(0.053)$ & -0.048 & $(0.063)$ \\
\hline Age2 & 0.000 & $(0.001)$ & 0.000 & $(0.001)$ & 0.001 & $(0.001)$ & 0.001 & $(0.001)$ \\
\hline Job similarity & $-0.273^{* *}$ & $(0.104)$ & $-0.301^{* *}$ & $(0.135)$ & $-0.338^{* *}$ & $(0.131)$ & $-0.377^{* *}$ & $(0.146)$ \\
\hline Previously self-employed & 0.089 & $(0.145)$ & 0.164 & $(0.244)$ & 0.008 & $(0.160)$ & -0.033 & $(0.202)$ \\
\hline Leadership & -0.115 & $(0.108)$ & -0.099 & $(0.134)$ & 0.071 & $(0.148)$ & 0.139 & $(0.207)$ \\
\hline Parental self-employment & -0.082 & $(0.109)$ & -0.052 & $(0.149)$ & -0.071 & $(0.135)$ & -0.041 & $(0.180)$ \\
\hline Married & 0.137 & $(0.150)$ & 0.115 & $(0.186)$ & -0.062 & $(0.186)$ & -0.160 & $(0.225)$ \\
\hline Children & 0.115 & $(0.164)$ & 0.244 & $(0.275)$ & 0.214 & $(0.209)$ & 0.335 & $(0.280)$ \\
\hline Foreign & 0.040 & $(0.202)$ & 0.043 & $(0.252)$ & 0.478 & $(0.318)$ & 0.559 & $(0.419)$ \\
\hline Single ownership & $0.302^{* *}$ & $(0.114)$ & $0.267^{* *}$ & $(0.145)$ & $0.416^{* *}$ & $(0.139)$ & $0.398^{* *}$ & $(0.171)$ \\
\hline Constant & 0.742 & $(0.844)$ & 0.421 & $(1.215)$ & 1.517 & (1.011) & 1.222 & $(1.425)$ \\
\hline Rho & $-0.959^{* *}$ & $(0.591)$ & -0.839 & $(0.861)$ & -0.793 & $(0.580)$ & -0.493 & $(0.977)$ \\
\hline Log likelihood & -794.22 & & -813.59 & & -832.03 & & -850.09 & \\
\hline$N$ & 1140 & & 1140 & & 1140 & & 1140 & \\
\hline$\chi^{2}$ & $72.31^{* *}$ & & $69.77^{* * *}$ & & $74.13^{* *}$ & & $69.88^{* *}$ & \\
\hline
\end{tabular}

Reported estimates are based on the bivariate model, standard errors in parentheses. ${ }^{* *}$ and ${ }^{*}$ indicate significance at the 5 and $10 \%$ level, respectively.

both commitments reduce the incidence of loan denial if we employ partly_denied as a dependent variable. Apparently, applicants may show their credibility to banks employing these commitments. As a consequence such applications are subject to less uncertainty and the bank is more likely to grant the application. Thus, credible commitments with respect to the recol- lection chances of a debt and the success chances of a new business increase the chance that a bank grants a credit.

Previous income, high education and age signal the chance to recollect the debt - even if the business fails - from the respondent's later income streams. We find some mixed evidence regarding the variable measuring previous income. When 
using fully_denied as a dependent variable Income $<2 \overline{5}, 000$ is significant. However, if we employ partly_denied it is not. The coefficient of high education is not significant in the denial estimations, but significant and negative in the application estimations. These results suggest that education is more a demand than a supply factor. Highly educated business starters may have a lower need for credit resulting in a negative effect on credit application. Thus, banks face a pool of applicants that is lower educated compared to all business starters (see also Table IV). This right truncation of education in the sample of applicants reduces the bank's decision discretion with respect to education probably resulting in a non-significant effect in the denial decision. The coefficient of the variable age is not significant indicating that banks do not account for differences in lifetime horizons when deciding on a credit application.

All other variables in the lower part of Table $\mathrm{V}$ refer to signals concerning the success chance of a new business venture. Signals related to the success chances of the business do not affect the banks' decision except for the variable job similarity. This suggests that banks tend to appreciate if applicants have performed tasks in their previous job, which are similar to the tasks performed once being self-employed. The coefficient of previously self-employed is not significantly different from zero. Also, the variables leadership, and parental self-employment, which are directly related to specific human capital in the form of entrepreneurial skills, do not have an effect. Applicants who were married, who have children or were born abroad (foreign) are not less likely to be denied a loan. It appears that applicants who intend to remain the single owner of the establishment are more likely to face credit rationing. Banks are slightly more likely to refute their request for funds since they are less likely to fully recollect the debt from a single owner in case of bankruptcy. Further, multiple-ownership may signal a higher degree of credibility of the application. Apparently our results indicate that banks do not care much about the increased complexity of the agency problem in case of multiple-ownership.

By and large, our analysis shows that indicators related to commitments have the expected effects while the indicators describing different signals show mixed and ambiguous results. It is striking that most of the variables that are significant in the equation explaining loan application, except for high education, are also significant in the denial equation. Apparently the applicants are capable of basing their application decision on parts of the denial procedure by the bank. This provides some evidence in favor of the hypothesis that business starters understand the credit rationing policy of the bank. In line with this we like to observe that the correlation coefficient RHO is always negative according to our estimates. This makes sense. Suppose that an applicant has a relatively low random error in the denial equation. This means that the applicant is less likely to be denied credit. Knowing this he or she will be more likely to apply which is captured by a relatively high random error term in the application equation.

We have also estimated our model under the constraint that RHO is equal to zero, since in most cases the coefficient is not significantly different from zero in our models. The main conclusions are: ${ }^{9}$ First, the estimates of the loan application model only change marginally and hence do not alter our previous results. Secondly, in the constrained model where RHO $=0$ the advice of an accountant becomes a more important factor reducing the chance of loan denial, whereas the presence of own equity becomes an insignificant variable. Being previously self-employed, having children and being born abroad (foreign) increase the chance of loan denial. The other conclusions regarding the unconstrained model remain largely valid in the constrained version of the model. We conclude this section by observing that we have also estimated a univariate probit model for the denial decision. However, the estimates yielded unexpected and implausible signs and are therefore disregarded. We take this observation as evidence in favor of the validity of the bi-variate model we employed.

\section{Conclusion}

The first question we address in this paper is: "Who experiences credit rationing when starting 
a business?" We have estimated a model that determines which features affect whether an application is denied or not by a financial institution and that simultaneously takes into account which individuals apply for a loan. It is important to integrate both decisions since some individuals may not apply for a loan since they expect to be unsuccessful. If applying for a loan is rather costly they will abstain from undertaking this effort. Such persons should be regarded rationed as well.

We argued that a bank's decision to approve or deny a credit application depends on commitments and signals provided by the potential entrepreneur showing the bank that the new venture's success is likely and repayment of the debt is highly probable. Our results indicate that personal wealth plays an important role. In line with Black et al. (1996) we find that home ownership is important to acquire access to external financial resources. Individuals that use own capital to fund their business are more likely to receive credit. Earning capacity, however, reduces full credit denial, but not partial denial. Apparently, banks take earning capacities into account, but reduce the risk of uncertain future income streams by rationing credit. These results reinforce our conclusion that banks value commitments more than signals. We find some evidence that the writing of a business plan and the support of an accountant enhance the credibility of a loan application. Small financial commitments, i.e. the incurred costs for writing a business plan and hiring an accountant seem to convince banks. The effects of a business plan and advice from an accountant point also at the fact, that banks are more likely to grant credit, if the provided information on the business is more trustworthy and reliable and less subject to an optimistic bias of the business founder.

Higher education significantly reduces the incentive to apply for credit, though it does not affect a bank's decision to deny or request for a loan or not. This result suggests that education is more a demand than a supply factor. Highly educated individuals may have no need to apply for credit. The results for other potential demand variables (own equity and previous income) show that business starters' decisions to apply for credit are driven by their assessment of supply factors, since higher levels of own equity and previous income increase the chance of loan application. Nevertheless, these results point at an issue worth investigating in the future, namely the interplay between demand and supply factors in the decision to apply.

Empirical studies on the survival of new businesses show that work experience, previous self-employment and leadership experience are positively related to success (see, e.g., Brüderl et al., 1992; Gimeno et al., 1997; van Praag, 1996). Our analysis suggests that banks appreciate if a potential business founder has gained relevant similar experience in a paid job, but are reluctant to value previous self-employment and leadership experience. Age does not affect credit rationing according to our results. Parental selfemployment, being married, the presence of children and being born abroad do not affect the probability of denial. The insignificant coefficient for foreigners seems to contradict other studies reporting that blacks are more credit constrained (see, e.g., Blanchflower et al., 1998; Cavaluzzo and Cavaluzzo, 1998; Raturi and Swamy, 1999; Storey, 2004). It should be noted, that according to those studies other ethnicities, such as Asians and Hispanic, are not constrained. In the Netherlands, most immigrants stem from countries neighboring the Mediterranean Sea and former Dutch colonies. Moreover, despite large differences between immigrant and incumbent citizens, the trench between those groups might be less severe than in other countries.

The indicators describing signals regarding the success chances and the chance to recollect the debt even if the business fails are mostly not significant with the exception of previous income and job similarity. This suggests that banks are rather reluctant in employing nonfinancial criteria in their credit decisions, although many studies provide support that for example parental self-employment enhances business success strongly. The findings regarding those signals are, however, in line with findings of previous studies on the effects of characteristics of the business owner and the firm (see section 3). Individuals who intend to remain the sole owner of the establishment are more 
likely to experience difficulties in receiving a loan. Our results also indicate the importance of self-employed contacts. Personal networks with other self-employed seem to raise an individual's ability to making a well-reasoned decision regarding the request for external financing.

The second issue we address in this paper is whether the business starters have some understanding regarding the rating policy of the bank. We find that the decision to apply or not is based on largely the same characteristics that determine the denial decision. Apparently, business starters foresee the decision procedure of the bank to a large extent and apply only if they expect that the application yields a reasonable success chance. Hence, credit rationing does not only affect individuals who submit a loan application at a bank. It also discourages individuals to apply for a loan if they know in advance that their request for a loan will be denied with high probability. For instance, if they don't own substantial financial resources or do not possess a home they will find it very hard to receive a loan even though their business idea is excellent. Hence, credit rationing also affects the decision to apply for a bank loan or not.

One limitation of our study arises from the used sample, which focuses on newly founded firms, which does not allow us to use measures associated with the firm's previous performance or borrowing behavior, as for example Cavaluzzo and Cavaluzzo (1998) do. Our indicators describing the business founders, their ability to repay the loan and their success chances, such as previous income and leadership experience, substitute, however, at least partly for the omission of any historic track record of the firm. Other similar studies, we mentioned in this paper, also include other characteristics of the firm as indicators for the risk associated with the specific venture. Our analysis does not include such variables, as at the time the entrepreneurs applied for credit, their business was not started yet. Hence, information on firm demographics or financial indicators were not available, although the business founder as well as the bank will have had some idea how the intended business will look like in terms of the legal form or the intended number of employees (size).

\section{Notes}

1 Harris and Raviv (1991) and Hubbard (1998) provide excellent reviews of the literature on capital constraints.

2 See Parker (2004) for a survey of the literature on financing entrepreneurial ventures.

3 See also Greene (1998) and Montmarquette et al. (2001) and the references cited therein for further details on the bivariate probit model with sample selection.

4 See Lopez-Gracia and Aybar-Arias (2000), Verheul and Thurik (2001) and the references cited therein.

5 In signaling games, in equilibrium costly messages may reveal the type of the sender. See for instance Myers and Majluf (1984) and Gibbons (1992).

6 We thank one of the reviewers for pointing us at this issue.

7 Though not reported in the table our data are likely to under-represent ICT businesses. We cannot make a strong conclusion here since the data provided by Dutch Statistics do not provide sufficient detail.

8 HFL (Hollandse Florijn) was the Dutch national currency (Dutch Guilder) at the time of the survey. HFL 1 equals approximately $€ 0.45$.

9 Results are not reported here, but are available from the authors upon request.

\section{References}

Ang, J. S., 1991, 'Small Business Uniqueness and the Theory of Financial Management', The Journal of Small Business Finance 1(1), 1-13.

Ang, J. S., 1992, 'On the Theory of Finance for Privately Held Firms', The Journal of Small Business Finance 1(3), 185-203.

Avery, R. B., R. W. Bostic and K. A. Samolyk, 1998, 'The Role of Personal Wealth in Small Business Financing', Journal of Banking and Finance 22(6), 1019-1061.

Bates, T., 1991, 'Commercial Bank Financing of White- and Black-Owned Small Business Start-ups', Quarterly Review of Economics and Business 31(1), 64-80.

Biggs, T., P. Raturi and M. Srivastava, 2002, 'Ethnic Networks and Access to Credit: Evidence from the Manufacturing Sector in Kenya', Journal of Economic Behavior and Organization 49(4), 473-486.

Black, J., D. de Meza and D. Jeffreys, 1996, 'House Prices, The Supply of Collateral and the Entreprise Economy', The Economic Journal 106(434), 60-75.

Blanchflower, D. G., P. B. Levine and D. J. Zimmerman, 1998, 'Discrimination in the Small Business Credit Market', NBER working paper series number 6840.

Blanchflower, D. G. and A. J. Oswald, 1998, 'What Makes an Entrepreneur?', Journal of Labor Economics 16(1), 26-60.

Blumberg, B. F. and G. A. Pfann, 2003, Zelfstandig Ondernemer in Zuid Limburg, Maastricht: Datawyse[Entrepreneur in South Limburg].

Brüderl, J., P. Preisendörfer and R. Ziegler, 1992, 'Survival Chances of Newly Founded Business Organizations', American Sociological Review 57(2), 227-242. 
Cavalluzzo, K. S. and L. C. Cavalluzzo, 1998, 'Market Structure and Discrimination: The Case of Small Businesses', Journal of Money, Credit and Banking 30(4), 771-792.

Cressy, R., 1996, 'Are Business Startups Debt-Rationed?', The Economic Journal 106(438), 1253-1270.

Evans, D. S. and B. Jovanovic, 1989, 'An Estimated Model of Entrepreneurial Choice under Liquidity Constraints', Journal of Political Economy 97(4), 808-827.

Gibbons, R., 1992, A Primer in Game Theory, New York: Harvester Wheatsheaf.

Gimeno, J., T. B. Folta, A. C. Cooper and C. Y. Woo, 1997, 'Survival of the Fittest? Entrepreneurial Human Capital and the Persistence of Underperforming Firms', Administrative Science Quarterly 42(4), 750-783.

Greene, W., 1998, 'Sample Selection in Credit-Scoring Models', Japan in the World Economy 10, 299-316.

Guiso, L., 1998, 'High-tech Firms and Credit Rationing', Journal of Economic Behaviour and Organization 35(1), 3959.

Harris, M. and A. Raviv, 1991, 'The Theory of Capital Structure', Journal of Finance 46(1), 297-355.

Holtz-Eakin, D., D. Joulfaian and H. S. Rosen, 1994a, 'Entrepreneurial Decisions and Liquidity Constraints', RAND Journal of Economics 25(2), 334-347.

Holtz-Eakin, D., D. Joulfaian and H. S. Rosen, 1994b, 'Sticking it Out: Entrepreneurial Survival and Liquidity Constraints', Journal of Political Economy 102(1), 53-75.

Hubbard, R. G., 1998, 'Capital Market Imperfections and Investment', Journal of Economic Literature 36(1), 193-225.

Honig, B., 1998, 'Who Gets the Goodies? An Examination of Microenterprise Credit in Jamaica', Entrepreneurship and Regional Development 10(4), 313-334.

Jappelli, T., 1990, 'Who is Credit Constrained in the US Economy', Quarterly Journal of Economics 105(1), 219-234.

Johansson, E., 2000, 'Self-employment and Liquidity Constraints: Evidence from Finland', Scandinavian Journal of Economics 102(1), 123-134.

Keasey, K. and R. Watson, 1993, Small Firm Management. Ownership, Finance and Performance, Oxford: Blackwell.

Keasey, K. and R. Watson, 2000, 'Interest Rate Premia on UK Small Firm Bank Borrowings. A Research Note', Journal of Business Finance and Accounting 27(1 \& 2), 247-259.
Kon, Y. and D. J. Storey, 2003, 'A Theory of Discouraged Borrowers', Small Business Economics 21(1), 37-49.

Levenson, A. R. and K. L. Willard, 2000, 'Do Firms get the Financing they want? Measuring Credit Rationing Experienced by Small Businesses in the US', Small Business Economics 14(1), 83-94.

Lindh, T. and H. Ohlsson, 1996, 'Self-Employment and Windfall Gains: Evidence from the Swedish Lottery', The Economic Journal 106(439), 1515-1526.

Lopez-Gracia, J. and C. Aybar-Arias, 2000, 'An Empirical Approach to the Financial Behaviour of Small and Medium Sized Companies', Small Business Economics 14(1), 55-63.

Montmarquette, C., S. Mahseredjian and R. Houle, 2001, 'The Determinants of University Dropouts: A Bivariate Probability Model with Sample Selection', Economics of Education Review 20, 475-484.

Munnell, A. H., G. M. B. Tootell, L. E. Browne and J. McEneaney, 1996, 'Mortgage Lending in Boston: Interpreting HMDA Data', American Economic Review 86(1), 25-53.

Myers, S. C. and N. S. Majluf, 1984, 'Corporate Financing and Investment Decisions When Firms Have Information That Investors Do Not Have', Journal of Financial Economics 13(2), 187-221.

Parker, S. C., 2004, The Economics of Self-Employment and Entrepreneurship, Cambridge: Cambridge University Press.

van Praag, C. M, 1996, Determinants of Successful Entrepreneurship, Amsterdam: Thesis Publishers.

Raturi, M. and A. V. Swamy, 1999, 'Explaining Ethnic Differentials in Credit Market Outcomes in Zimbabwe', Economic Development and Cultural Change 47(3), 585-604.

Stiglitz, J. and A. Weiss, 1981, 'Credit Rationing in the Market with Imperfect Information', American Economic Review 71(3), 393-409.

Storey, D. J., 1993, 'New Firm Growth and Bank Financing', Small Business Economics 6, 139-150.

Storey, D. J., 2004, 'Racial and Gender Discrimination in the Micro Firms Credit Market? Evidence from Trinidad and Tobago', Small Business Economics 23(5), 401-422.

Verheul, I. and R. Thurik, 2001, 'Start-Up Capital: 'Does Gender Matter?", Small Business Economics 16(4), 329-345. 